\title{
AVPR2 wt Allele
}

National Cancer Institute

\section{Source}

National Cancer Institute. AVPR2 wt Allele. NCI Thesaurus. Code C51427.

Human AVPR2 wild-type allele is located within Xq28 and is approximately $5 \mathrm{~kb}$ in length.

This allele, which encodes vasopressin V2 receptor protein, is involved in the maintenance

of water homeostasis and $\mathrm{G}$ protein-coupled receptor signal transduction. When the

function of the gene is absent, it results in Nephrogenic Diabetes Insipidus (NDI). 